\title{
Hak Ekonomi Perempuan dalam Keluarga Perspektif Islam
}

\author{
Mu'amaroh \\ Institut Agama Islam Nahdlatul Ulama Tuban \\ E-mail: Muamaroh281@gmail.com
}

\begin{abstract}
Abstrak: Hak Ekonomi Perempuan dalam Perspektif Islam. Ketimpangan gender di bidang ekonomi membuat perempuan cenderung sulit untuk mengakses hak ekonominya. Komnas Perempuan sebagai salah satu lembaga HAM Nasional dalam kerjanya selalu menyisir dari kelompok rentan dan mengalami lapis-lapis diskriminasi terhadap perempuan. Dalam proses pemantauan, mendapati berbagai persoalan baik publik maupun domestik, baik hak sipil politik maupun hak ekonomi,sosial, dan budaya, baik pelakunya negara maupun anggota keluarga. Akses perempuan untuk mendapatkan kehidupan yang layak masih sangat sempit. Dari diskriminasi mengenai hak perempuan juga berdampak pada hak politiknya. Sulitnya dalam pengaksesan hak politik yang didapati perempuan karena marginalisasi perempuan asli tanpa tindakan afirmasi. Maksudnya adalah suatu proses peminggiran dengan cara asumsi gender tanpa adanya pernyataan. Akan tetapi Islam memberikan kesamaan hak antara laki-laki dan perempuan termasuk dalam bidang ekonomi. Dalam hal ini, perempuan memiliki arti untuk mendapatkan hak untuk ikut andil dalam pembangunan ekonomi. Kesetaraan dan keadilan untuk memiliki martabat kemanusiaan yang sama dengan laki-laki, termasuk tanggung jawab yang sama dalam pembangunan ekonomi masyarakat.

Kata kunci: Hak ekonomi, diskriminasi, perempuan, Islam.
\end{abstract}

\section{Pendahuluan}

Gender merupakan perbedaan dan persamaan non biologis antara perempuan dan laki-laki. Dalam istilah gender, kesetaraan antara lakilaki dan perempuan sering dibandingkan. Keseteraan yang dimaksud adalah kesetaraan hak sebagai makhluk hidup. Hak perempuan dan lakilaki itu sama dalam sektor suatu negara. Di dalam Islam, perempuan dan laki-laki itu sama, yang membedakan hanyalah dalam hal ketaatan kepada Allah SWT, diluar itu perempuan dan laki-laki setara baik dalam pendidikan, politik, ekonomi dan lainnya. Islam tidak pernah melarang perempuan untuk berkiprah dalam pembangunan ekonomi, bahkan 
untuk jadi pemimpin suatu negara.

Hanya saja, tradisi dari masyarakat Islam itu sendiri yang menghasilkan pemikiran bahwa perempuan hanya bertugas mengurus rumah tangga. Karena keberadaan dan posisi perempuan di dunia ini menimbulkan kontroversi. Sebagai akibat dari keadaan tersebut, perempuan membutuhkan aturan yang melegitimasi keadaannya, baik aturan perundang-undangan maupun aturan yang lebih mendasar, yaitu agama. Pada titik inilah urgensi dari hak ekonomi perempuan dalam perspektif islam. Kesetaraan dan keadilan bagi kaum perempuan secara komprehensif yang memposisikan perempuan sebagai makhluk yang memiliki martabat kemanusiaan yang sama dengan laki-laki serta tanggung jawab yang sama di segala bidang.

Hak-hak perempuan tanpa diskriminasi berlaku secara universal berdasarkan Hak Asasi Manusia. Pemenuhan hak ekonomi perempuan harus dirasakan dengan porsi yang sama terhadap perempuan. Peran perempuan dalam perekonomian nasional telah tertuang baik di dalam UUD 1945, maupun di beberapa regulasi lainnya seperti UU, PP, Peraturan Menteri, dan lain sebagainya. Secara Internasional, hak ekonomi perempuan diakui dalam konvensi anti diskriminasi CEDAW dan ILO. ${ }^{1}$

\section{Metode Penelitian}

Tulisan ini menerapkan pendekatan analisis kualitatif. Data didapatkan dari dokumen berupa Alquran, buku-buku, artikel jurnal, dan peraturan perundang-undangan yang relevan dengan hal-hal yang dikaji. Berdasarkan data yang didapatkan dilakukan analisis dengan menerapkan QDA (Qualitatif Data Analisis). QDA dilakukan dengan cara: mengidentifikasi dan mereduksi data mentah terhadap data yang bias, kemudian data yang relevan dikumpulkan dan dikategorikan berdasarkan hal-hal yang dikaji berdasarkan teori dan temuan penelitian sebelumnya sampai didapatkan jawaban terhadap hal-hal yang dikaji dan langkah terakhir adalah mengidentifikasi kesimpulan.

\section{Hasil dan Pembahasan}

Dalam hal ekonomi, hak milik dan wilayah kerja perempuan dibatasi, sehingga menjadikan perempuan sulit mengakses sumber daya ekonomi. Sebagai akibatnya, perempuan menjadi sangat tergantung kepada laki-

1 UU NO.7 Tahun 1984 Tentang Konvensi Mengenai Penghapusan Segala Bentuk Diskriminasi Terhadap Perempuan (CEDAW). 
laki dalam hal ekonomi. Implikasi lebih jauh akibat ketergantungan tersebut perempuan kehilangan kemandirian yang menjadikan mereka rentan terhadap berbagai diskriminasi, subordinasi, marjinalisasi dan bahkan kekerasan baik dalam keluarga maupun di wilayah publik. ${ }^{2}$

Dalam UU Nomor 39 Tahun 1999 tentang HAM yang berbunyi “...seperangkat hak yang melekat pada hakikat dan keberadaan manusia sebagai makhluk Tuhan Yang Maha Esa dan merupakan anugerah-Nya yang wajib dihormati, dijunjung tinggi dan dilindungi oleh negara, hukum, Pemerintah, dan setiap orang demi kehormatan serta perlindungan harkat dan martabat manusia" (Pasal 1 ayat 1). Dengan adanya UU HAM, semua peraturan perundang-undangan harus sejalan dengan prinsip-prinsip perlindungan HAM. Diantaranya penghapusan diskriminasi berdasarkan agama, suku, ras, etnik, kelompok, golongan, status sosial, status ekonomi, jenis kelamin, bahasa, dan keyakinan politik. Pelarangan diskriminasi diatur dalam Pasal 3 ayat (3), yang berbunyi: "Setiap orang berhak atas perlindungan hak asasi manusia dan kebebasan dasar manusia, tanpa diskriminasi". Pasal 1 ayat (3) dan Pasal 3 ayat (3) menjelaskan bahwa diskriminasi berdasarkan jenis kelamin telah dilarang oleh hukum. Aturan hukum lainnya harus meniadakan diskriminasi dalam setiap aspek kehidupan, sosial, politik, ekonomi, budaya dan hukum.

Pasal-pasalnya dalam UU HAM ini selalu ditujukan kepada setiap orang. Hal ini berarti semua hal yang diatur dalam UU HAM ditujukan bagi semua orang dari semua golongan dan jenis kelamin apapun. Inpres Nomor 9 Tahun 2000 tentang Pengarustamaan Gender (PUG) memberikan petunjuk adanya keseriusan pemerintah dalam upaya untuk menghilangkan bentuk diskriminasi dalam seluruh sendi kehidupan bernegara. Dalam konsideran Inpres ini disebutkan dua hal, yaitu:

1. Dalam rangka meningkatkan kedudukan, peran, dan kualitas perempuan, serta upaya mewujudkan kesetaraan dan keadilan gender dipandang perlu melakukan strategi pengarusutamaan gender ke dalam seluruh proses pembangunan nasional.

2. Bahwa pengarusutamaan gender ke dalam seluruh proses pembangunan merupakan bagian yang tidak terpisahkan dari kegiatan fungsional semua instansi dan lembaga pemerintah di tingkat pusat dan daerah. Inpres ini menjadi dasar adanya perspektif

\footnotetext{
${ }^{2}$ Muhammad Husein. Islam Agama Ramah Perempuan, (Yogyakarta: LkiS, 2004), hlm. 23
} 
gender bagi seluruh kebijakan dan program pembangunan nasional, tanpa terkecuali. Baik kebijakan di pusat maupun di daerah haruslah berperspektif gender, apabila tidak maka kebijakan tersebut harus diganti.

Perjuangan perempuan dalam mengakhiri sistem yang tidak adil (ketidakadilan gender) tidaklah merupakan perjuangan perempuan melawan laki-laki, melainkan perjuangan melawan sistem dan struktur ketidakadilan masyarakat, berupa ketidak adilan gender. Komnas Perempuan sebagai salah satu lembaga HAM Nasional dalam kerjanya selalu menyisir dari kelompok rentan dan mengalami lapis-lapis diskriminasi terhadap perempuan. Dalam proses pemantauan, mendapati berbagai persoalan baik publik maupun domestik, baik hak sipil politik maupun hak ekonomi,sosial, dan budaya, baik pelakunya negara maupun anggota keluarga. Akses perempuan untuk mendapatkan kehidupan yang layak masih sangat sempit. Dari diskriminasi mengenai hak perempuan juga berdampak pada hak politiknya. Sulitnya dalam pengaksesan hak politik yang didapati perempuan karena marginalisasi perempuan asli tanpa tindakan afirmasi. Maksudnya adalah suatu proses peminggiran dengan cara asumsi gender tanpa adanya pernyataan.

Beban reproduksi perempuan (mengandung, melahirkan, menyusui dan mengasuh anak) dijadikan justifikasi untuk membatasi akses perempuan ke wilayah publik termasuk hak bekerja. Fenomena ketimpangan struktural berupa keterbatasan kaum perempuan untuk memperoleh pendidikan, memperoleh akses ekonomi (misalnya bekerja untuk memperoleh penghasilan dan bukan sebatas menjalankan peran sebagai ibu rumah tangga), berorganisasi, dan lain sebagainya masih tetap marak. ${ }^{3}$ Prinsip dan ketentuan dalam CEDAW diperkuat oleh Deklarasi Wina 1993 yang mengakui dan menyatakan bahwa sebagai manusia, perempuan terlahir dengan hak asasi yang melekat, menyatu dan tidak terpisahkan dari hak asasi manusia yang universal. Bahwa hak perempuan adalah Hak Asasi Manusia, karenanya perempuan memiliki hak penuh dan sama dengan yang lain dalam bidang kehidupan ekonomi, sosial, budaya, sipil, dan politik. Indonesia khususnya negara yang terikat pada konstitusi. Negara yang dimana dalam pasal 27 dan 28 pada UUD

\footnotetext{
${ }^{3}$ Bidang Pengarusutamaan Gender Bidang Ekonomi, Kebijakan dan Strategi Peningkatan Produktifitas Ekonomi Perempuan, (Jakarta: Kementerian Pemberdayaan Perempuan \& Perlindungan Anak Republik Indonesia, 2012) hlm. 1
} 
Republik Indonesia 1945 yang mengatur tentang Hak Asasi Manusia warga negaranya. Pemerintah sebagai pemegang utama mandat konstitusi, wajib mengakui, memajukan, melindungi dan memenuhi Hak Asasi Manusia sebagai warga negara tanpa pengecualian. Namun hal ini tidak mengurangi atau menghilangkan kewajiban yang sama dari pihak masyarakat. Sebab dalam banyak kasus mengenai pengabaian dan pelanggaran terhadap hak-hak manusia, khususnya diskriminasi terhadap perempuan.

Sejarah awal Islam mencatat partisipasi aktif perempuan di ruang publik dalam upaya Nabi Muhammad Saw dan generasi awal Muslim membangun peradaban Islam yang egaliter. 4 Bahkan di Madinah, perempuan berpartisipasi aktif di ruang publik baik dalam hal intelektual dengan terlibat dalam transmisi wahyu al-Qu'ran dan Sunah/Hadis Nabi maupun dalam berbagai perdebatan ketika beberapa perkara menyangkut hak-hak mereka diputuskan. Dalam hal politik, mereka terlibat dalam pengambilan keputusan publik serta terlibat aktif dalam memimpin dan peperangan.

Sebagai bukti bahwa islam adalah agama yang tidak membatasi perempuan dalam hak ekonominya adalah ketika beberapa sahabat perempuan menunjukkan ketokohan mereka dalam partisipasi di bidang ekonomi. Istri Nabi, Khadijah r.a., merupakan tokoh pengusaha perempuan sukses yang kaya raya di Makkah. Rafidhah Aslamiyyah tercatat sebagai manager rumah sakit Islam pertama. Samrâ' binti Nuhyak Al-Asadiyyah juga tercatat sebagai petugas wilayah hisbah yang mengawasi aktifitas perdagangan di pasar. Sepeninggal Nabi, para istri beliau tidak diperkenankan untuk menikah dengan laki-laki lain. Khalifah 'Umar menyadari perlunya memberikan dukungan finansial dengan memberikan pensiun kepada setiap janda Nabi. Ia menawarkan pensiun sebesar 12.000 dirham setahun untuk Aisyah dan tunjangan yang lebih kecil untuk janda lainnya dengan skala yang berbeda-beda hingga yang paling kecil 5.000 dirham. Tawaran ini dipandang oleh para janda kurang mencukupi sehingga mereka komplain dan meminta 'Umar untuk mempertimbangkan kembali nilai nominalnya. Tuntutan mereka akhirnya dikabulkan. 'Umar menaikkan nilai pensiun hingga 10.000 dirham sedangkan Aisyah tetap memperoleh 12.000 dirham per tahun. Catatan sejarah mengenai transaksi properti juga mengilustrasikan kemampuan

${ }^{4}$ Nadia Abbot, Aishah: The Beloved of Muhammad, (London: Saqi Books, 1985), hlm.95 
berjual beli para janda Nabi, misalnya Sawdah yang menghibahkan apartemennya kepada Aisyah dan Aisyah menjualnya dengan harga 180.000 dirham. Aisyah juga mengembangkan penghasilan pensiun yang ia terima dengan terlibat dalam perdagangan. Contoh-contoh ini menunjukkan bagaimana perempuan muslimah cukup asertif dalam memperjuangkan kepentingan finansial mereka.

Pada masa Islam selanjutnya, sejarah mencatat perempuan Muslimah memiliki kemampuan mengelola aset-aset ekonominya dengan baik. Misalnya pada abad ke-16 tercatat sepertiga pendiri yayasan wakaf di Istanbul merupakan perempuan. Demikian pula di pengadilan, perempuan secara mandiri mampu mengurus berbagai sengketa yang melibatkan hak-hak properti mereka. ${ }^{5}$ Namun demikian, bukti-bukti dokumenter ini pun perlu disikapi dengan kritis. Demikian pula pengaruh budaya setempat ketika hukum Islam diformulasikan telah menyebabkan bias-bias patriarki ikut mewarnai penafsiran teks-teks Islam.

Masih banyak lagi perempuan Islam yang mampu membuktikan diri sebagai manusia yang memiliki potensi tak kalah dengan laki-laki. Sejarah Islam Nusantara juga menjelaskan betapa perempuan memiliki kemampuan yang sama dengan laki-laki dalam hal berpolitik. Tercatat ada empat sultanah (ratu) yang sempat memerintah Kerajaan Aceh Darussalam. Mereka adalah Sri Ratu Safi al-Din Taj al-Alam yang bergelar Paduka Sri Sultanah Ratu Safiatuddin Tajul-'Alam Shah Johan Berdaulat Zillullahi fil-'Alam binti al-Marhum Sri Sultan Iskandar Muda Mahkota Alam Shah (1641-1675 M ), Sri Ratu Naqi al-Din Nur al-Alam yang bergelar Sultanah Nurul Alam Naqiyatuddin Syah (1675-1678 M), Sri Ratu Zaqi al-Din Inayat Syah yang bergelar Sultanah Zakiatuddin Inayat Syah (1678-1688 M) dan Sri Ratu Kamalat Syah Zinat al-Din yang bergelar Sultanah Zinatuddin Kamalat Syah (1688-1699 M). Begitu mulia dan terhormatnya kedudukan perempuan dalam Islam.

Seorang ulama kontemporer dari Al-Azhar Mesir, Muhammad alGhazali menuturkan seperti yang dikutip Quraish Syihab: "Kalau kita mengembalikan pandangan ke masa sebelum seribu tahun, maka kita akan menemukan perempua menikmati keistimewaan dalam bidang materi dan sosial yang tidak dikenal oleh perempuan-perempuan di lima

${ }^{5}$ Sugiarti Handayani. Konsep dan Teknik Penelitian Gender, (Malang: UMM Press, 2002) hlm. 15 
benua. Keadaan mereka ketika itu lebih baik dibandingkan dengan keadaan perempuan-perempuan Barat dewasa ini, asal saja kebebasan dalam berpakaian serta pergaulan tidak dijadikan sebagai bahan perbandingan".

Menurut ahli tafsir Indonesia, Quraish Syihab, munculnya pandangan miring yang seakan-akan membatasi peran perempuan serta mengaburkan keistimewaan dan memerosotkan kedudukan perempuan antara lain disebabkan karena kedangkalan pengetahuan keagamaan dan kesalahan penafsiran teks atau nash keagamaan, ${ }^{6}$ sehingga sering kali agama dijadikan alat untuk membenarkan pandangan yang salah ini (Syihab, 1993, hal. 4). Jadi, agama Islam yang semula lahir dengan membawa missi liberasi, membebaskan perempuan dari keterkungkungan dan ketertindasan dan mendudukannya pada posisi terhormat, lambat laun berubah justru menjadi alat justifikasi bagi terulangnya pemasungan hak-hak perempuan akibat dari keterbatasan pengetahuan agama dan misinterpretasi terhadap teks-teks kitab sucinya. Maka, yang terjadi adalah apa yang kemudian kita bisa lihat dalam kehidupan masyarakat tradisional. Perempuan hanya diperbolehkan berkiprah dalam wilayah privat dan sangat dibatasi berkiprah dalam ranah publik.

Hak ekonomi perempuan adalah pemberdayaan ekonomi yang dapat mendorong kesetaraan gender yang adil dan inklusif. Perempuan yang berdaya secara ekonomi, memiliki akses lebih luas terhadap aset ekonomi dan kontrol besar atas pendapatan.

Pemberdayaan hasil terjemahaan dari kata empowerment, arti kata empower menurut Webster dan OED (Oxford English Disctionary) adalah to give power or outhority to, artinya sebagai memberi kekuasaan, mengalihkan kekuatan atau delegasi otoritas ke pihak lain. ${ }^{7}$

Pranarko dan Prijono mendefinisikan pemberdayaan sebagai " proses kepada masyarakat agar menjadi berdaya, mendorong atau memotivasi individu agar mempunyai kemampuan atau keberdayaan untuk menentukan pilihan hidupnya, dan memberdayakan harus ditujukan pada kelompok atau lapisan masyarakat yang tertinggal. Konsep pemberdayaan perempuan ini pada dasarnya merupakan paradigma baru

${ }^{6}$ Quraish Shihab, Perempuan, (Banten : Lentera Hati, 2015), hlm. 35

7 Yeni Huriani, Encep Dulwahab, Nablurrahman Annibras, Strategi Penguatan Ekonomi Perempuan Berbasis Keluarga. 2021, hlm. 6 
dalam perkembangan pembangunan yang lebih mengasentuasikan sifatsifat people centered, participatory emproving sustainable. ${ }^{8}$

Perempuan mempunyai kemampuan sama halnya kemampuan yang dimiliki seorang lelaki dalam berbagai bidang. Prosentase jumlah penduduk perempuan adalah setengah dari jumlah penduduk dunia, jadi tak heran jika perempuan juga turut andil menjadi agen pembangunan sebagaimana laki-laki. Fakta menarik bahwa di Indonesia sendiri pernah dipimpin oleh seorang presiden perempuan, yaitu Megawati Soekarno Putri. Dan ini menjadi realitas yang tak bisa dibantah bahwa perempuan bisa turut berkiprah dalam pembangunan.

Selain itu, banyak perempuan yang berada pada pengaruh yang besar terhadap Indonesia sendiri yaitu salah satunya adalah Najwa Shihab, putri dari ahli tafsir Quraish Shihab. Perempuan yang satu ini sangat besar perannya karena selain sebagai perempuan yang berkecimpung di dunia jurnalis, beliau juga sering menyuarakan hak-hak perempuan. Mari kita lihat betapa revolusioner Al-quran serta Nabi Muhammad SAW dalam memuliakan perempuan. Dalam Alquran surat An-Nahl 97 dijelaskan: "Barangsiapa yang mengerjakan amal shaleh baik laki-laki maupun perempuan sedangkan ia beriman, maka sungguh akan Kami berikan kepadanya kehidupan yang lebih baik, dan sesungguhnya akan Kami beri balasan atas apa yang telah mereka kerjakan". ${ }^{9}$

Demikian juga dengan surat At-Taubah ayat 31, "Dan orang-orang yang beriman, laki-laki dan perempuan, sebagian mereka menjadi penolong bagi sebagian yang lain. Mereka menganjurkan yang ma'ruf, mencegah kemungkaran, mendirikan sholat, menunaikan zakat, dan mereka taat kepada Allah dan Rasul-Nya. Mereka itu akan diberi rahmat oleh Allah. Sesungguhnya Allah Maha Perkasa lagi Maha Bijaksana". ${ }^{10}$ Ayat-ayat ini, dan banyak ayat lain yang serupa menegaskan betapa Allah SWT memberikan porsi yang sama antara perempuan dan laki-laki, baik dalam potensi maupun dalam berkompetisi menjadi insan terbaik. Apalagi Alquran juga menjelaskan bahwa keduanya diciptakan juga dari jiwa yang satu (min nafsiwwahidah) QS. An-Nisa 1. Dalam Islam, relasi antara perempuan dan laki-laki adalah partnership, "sebagian kamu

\footnotetext{
8 Yeni Huriani, Encep Dulwahab, Nablurrahman Annibras, Strategi Penguatan Ekonomi Perempuan Berbasis Keluarga, hlm. 10

${ }^{9}$ Q.S. An-Nahl : 97

${ }^{10}$ Q.S. At-Taubah : 31
} 
adalah bagian dari sebagian yang lain". (QS Ali Imran 195). Atau "sebagian mereka menjadi penolong bagi sebagian yang lain".

Islam sesungguhnya telah memberikan landasan bagi upaya peningkatan hak-hak ekonomi dan kesetaraan gender dalam masyarakat Muslim. Namun karena pengaruh budaya dan struktur politik serta keagamaan yang masih merefleksikan bias-bias patriarki maka perlu upaya revitalisasi hak-hak perempuan termasuk hak-hak ekonomi dan kesetaraan perempuan dengan laki-laki baik di wilayah privat maupun publik. Selain perubahan paradigma melalui penafsiran ulang tersebut upaya ini perlu diperkuat melalui upaya-upaya pemberdayaan.

Dalam Islam, ajaran pemberdayaan ini termaktub dalam QS. Al-Ra'd ayat 11: "Sesungguhnya Allah tidak akan merubah nasib suatu kaum hingga kaum tersebut merubahnya". Pemberdayaan ekonomi perempuan Muslimah ${ }^{11}$ melalui peningkatan partisipasi ekonomi memiliki urgensi signifikan karena perempuan membentuk setengah populasi dunia. Cukup banyak perempuan Indonesia yang menunjukkan bahwa dirinya mampu bersaing sekaligus memberikan kontribusi yang tidak kalah besarnya dalam berbagai bidang pembangunan, mulai dari ilmu pengetahuan, teknologi, politik, ekonomi, sosial, dan bahkan pertahanan dan keamanan. Apabila setengah populasi ini tidak aktif secara ekonomi maka perekonomian negara mengalami penurunan dari segi produktifitas. Bertolak dari paparan di atas, sepantasnya timbul pertanyaan, seberapa jauh sebenarnya perempuan telah mendapatkan hak-haknya dari proses pembangunan yang berlangsung.

Sebagaimana diketahui perlindungan atas hak-hak hidup manusia secara umum termuat dalam Deklarasi Hak Asasi Manusia. Isi kandungan deklarasi tersebut terbagi atas empat tonggak utama. Tonggak pertama adalah hak-hak pribadi, termasuk di dalamnya adalah hak persamaan, hak hidup, kebebasan, keamanan dan sebagainya. Kedua, hak-hak yang dimiliki oleh individu dalam hubungannya dengan kelompok-kelompok sosial di mana dia ikut serta, termasuk di dalamnya adalah hak kerahasiaan kehidupan keluarga dan hak untuk kawin, kebebasan bergerak di dalam atau di luar negara nasional, untuk memiliki kewarganegaraan dan suaka dalam keadaan penindasan dan lain-lain. Ketiga, hak kebebasan sipil dan hak politik yang dilaksanakan untuk

${ }^{11}$ Ahmad Rifa'i, The Perfect Muslimah, (Jakarta: PT. Elex Media Komputindo, 2012), hlm. 126. 
memberikan andil bagi pembentukan instansi-instansi pemerintah dan ikut serta dalam proses pembuatan keputusan. Hak berserikat, hak menyatakan pendapat, hak untuk memilih dan dipilih termasuk dalam kategori ini. Keempat, hak yang dilaksanakan dalam bidang ekonomi dan sosial. Dalam bidang ini termasuk perlindungan dalam hak untuk bekerja, mendapatkan jaminan sosial, hak untuk mendapatkan jaminan kesehatan dan lain-lain.

Setiap manusia yang sehat harus bisa mencukupi kebutuhan diri dan keluarganya. Untuk mencapai itu, maka tersedia berbagai fasilitas untuk menjadikan seseorang baik laki-laki maupun perempuan itu bisa menjadi produkif. Melalui pengembangan kemampuanya perempuan bisa diberikan kesempatan untuk berwirausaha dan bekerja untuk mendapatkan gaji. ${ }^{12}$

Islam memiliki misi pemberdayaan, yaitu;

1) Misi membangun ekonomi dan bisnis yang berpedoman pada ukuran-ukuran ekonomi dan bisnis Islam.

2) Pelaksanaan etika dan ketentuan hukum syariah yang harus menjadi ciri kegiatan umat Islam.

3) Membangun kekuatan ekonomi Islam sehingga menjadi sumber dana pendukung dakwah.

Dalam implementasinya sangat dirasa kurang, karena masih ada pemenuhan gaji yang masih belum layak. Implikasinya adalah terjadi peningkatan pekerja laki-laki dalam industri lapangan kerja. Hal semacam ini perlu adanya pemerhati sekala makro. Bahwa keberadaan tenaga kerja perempuan bisa mendorong perekonomian negara dalam semua aspek. Seperti pada era Orde Baru yang lebih membuka kesempatan kerja untuk perempuan di sektor manufaktur. Hal ini ditandai dengan banyak berdirinya pabrik-pabrik dengan produk massal, seperti garmen, tekstil, sepatu, dan mainan anak-anak untuk pasar dunia. Naiknya Tingkat Partisipasi Angkatan Kerja (TPAK) perempuan saat itu di sektor manufaktur menyebabkan naiknya sumbangan mereka terhadap pertumbuhan ekonomi Orde Baru yang rata-rata enam persen.

Namun, hal itu ternyata tidak diikuti oleh perbaikan kesejahteraan mereka. Hal ini terbukti dengan masih adanya diskriminasi upah, diskriminasi karier maupun terjadinya eksploitasi dan kekerasan seksual terhadap buruh perempuan. Segala kekurangan itu masih ditambah oleh

${ }_{12}$ M. umer chapra, Islam dan pembangunan ekonomi, (Tazkia institute: Jakarta, 2000), hlm.9. 
pengabaian pemerintah terhadap masalah perlindungan terhadap buruh perempuan migran yang telah berjasa mendatangkan devisa. Dari kekurangan-kekurangan itu,diskriminasi merupakan realitas yang paling nyata dalam persoalan buruh perempuan Indonesia. Selama pemerintahan Orde Baru, diskriminasi itu setidaknya dapat digolongkan dalam dua kategori: (a) dari segi standar penentuan besarnya nilai upah dan (b) dari segi besar dan mekanisme penentuan upah.

Standar penentuan besarnya nilai upah sejak awal sudah tidak adil bagi buruh perempuan, karena penentuan besarnya nilai upah didasarkan pada konsep KFM, dengan perinciannya yang didasarkan pada standar hidup buruh pada tahun 1950-an, bukan menggunakan konsep kebutuhan hidup minimum (KHM). Penetapan dengan dasar KFM, selain tidak sesuai dengan tingkat kebutuhan saat ini, standar ini juga bias gender, karena komponen KFM sangat mendasarkan kebutuhan fisik laki-laki dan tidak menghitung berbagai kebutuhan fisik minimun seorang perempuan, paling tidak yang berhubungan dengan perundungan terhadap organorgan reproduksi. Perbedaan kebutuhan gizi antara perempuan dengan laki-laki pun tidak dimasukkan dalam perhitungan standar upah. Dari segi konsentrasi, perubahan juga terjadi seiring dengan pembangunan yang dilaksanakan. Secara umum, terlihat pergeseran (shifting) pekerja anak dari sektor pertanian menuju sektor jasa dan industri. Terdapat indikasi bahwa para pemilik modal lebih suka menggunakan anak dan wanita sebagai pekerja. Alasannya, pekerja anak dan wanita tidak banyak melakukan tuntutan dan bersedia dibayar murah.

Ini berbeda dengan pemenuhan hak dan kebebasan dasar yang menekankan bahwa pemerintah tidak boleh melakukan apa pun (abstention) berkenaan dengan hak individu, termasuk hak perempuan. Sebagai contoh, pemerintah tidak boleh mencampuri hak rakyat (dalam artian perempuan juga termasuk hak rakyat, karena perempuan juga mengisi peran dalam bermasyarakat).

Melihat kondisi saat ini, penting bagi perempuan untuk berdaya di sektor ekonomi. Meski sampai saat ini belum ada definisi tunggal mengenai Pemberdayaan Ekonomi Perempuan. Pemberdayaan ekonomi perempuan sebagai proses yang meningkatkan kekuatan nyata perempuan atas keputusan ekonomi yang mempengaruhi kehidupan dan prioritas mereka dalam masyarakat. Pemberdayaan ekonomi perempuan dapat dicapai melalui akses dan kontrol yang sama atas sumber daya dan 
peluang ekonomi kritis, penghapusan struktur ketidaksetaraan gender di pasar tenaga kerja, termasuk pembagian pekerjaan perawatan tidak berbayar yang lebih baik.

Strategi pemberdayaan dalam Islam telah difikirkan, yaitu dengan cara melalui kebijakan fiscal, diantaranya;

a. Mengembangkan ilmu pengetahuan dan teknologi

b. Mengembangkan kebutuhan dasar manusia

c. Mengratiskan fasilitas kesehatan

d. Memberantas kemiskinan dan kepincangan pendapatan masyarakat. ${ }^{13}$

Sementara dalam dokumen Oxfam's Conceptual Framework on Women's Economic Empowerment (2017) disebutkan bahwa pemberdayaan ekonomi yang efektif bagi perempuan terjadi ketika perempuan menikmati hak mereka untuk mengontrol dan mengambil manfaat dari sumber daya, aset, pendapatan, dan waktu mereka sendiri, dan ketika mereka memiliki kemampuan untuk mengelola risiko dan meningkatkan status ekonomi dan kesejahteraan mereka.14 Untuk dapat berdaya perempuan harus memiliki otonomi dan kepercayaan diri untuk membuat perubahan dalam hidup mereka sendiri, termasuk memiliki hak pilihan dan kekuasaan untuk mengatur dan mempengaruhi pengambilan keputusan, sambil menikmati hak yang sama dengan laki-laki dan bebas dari diskriminasi.

Perempuan memberikan kontribusi yang sangat besar pada perekonomian, baik dalam bisnis, di pertanian, sebagai pengusaha atau karyawan, atau dengan melakukan pekerjaan perawatan tidak berbayar di rumah. Pemberdayaan ekonomi perempuan hadir sebagai salah satu upaya untuk menuju kesetaraan gender, pengentasan kemiskinan dan pertumbuhan ekonomi yang inklusif.

Pertanyaan yang kemudian hadir, apa yang diperlukan agar Pemberdayaan Ekonomi Perempuan dapat tercapai? Oxfam merangkum, setidaknya terdapat enam faktor yang dapat mendukung realisasi Pemberdayaan Ekonomi Perempuan. Keenam faktor tersebut adalah sebagai berikut: Kemampuan perempuan untuk berpartisipasi dan memimpin dalam pengambilan keputusan dan tindakan kolektif; Kemampuan perempuan untuk mempertahankan pekerjaan dengan upah layak, berpartisipasi dalam atau memimpin perusahaan, atau pensiun

${ }^{13}$ M. Dawan Rahardjo, Islam dan pembangunan ekonomi, (Jakarta: Tazkia institud, 2000), hlm. 70-72. 
dengan tabungan yang cukup; Pengurangan dan pembagian tanggung jawab kerja perawatan; Kontrol perempuan atas pendapatan, aset, dan sumber daya alam dalam rumah tangga dan berhadapan dengan lembaga formal dan tradisional; Kemampuan perempuan untuk hidup bebas dari kekerasan dengan percaya diri, mobilitas, keamanan (tanpa pelecehan), agen, dan organisasi untuk mengakses pasar; Kemampuan perempuan untuk membangun ketahanan mereka terhadap guncangan eksternal, perubahan iklim dan risiko terkait.

Oleh karena itu berbagai upaya dilakukan untuk meningkatkan kesetaraan laki-laki dan perempuan termasuk di bidang ekonomi. MDGs mengamanatkan tiga bidang utama upaya peningkatan kesetaraan gender yaitu peningkatan partisipasi perempuan di bidang pendidikan, ekonomi (akses pada pekerjaan dan penghidupan yang baik) dan representasi politik. Akses perempuan terhadap pendapatan dapat meningkatkan otonomi, status ekonomi dan sosial mereka. Ia juga dapat merubah relasi kuasa antara perempuan dan laki-laki, termasuk di level rumah tangga, misalnya dengan meningkatnya kontrol perempuan terhadap budget rumah tangga yang akan dibelanjakan. Memperbaiki kesempatan ekonomi perempuan juga merupakan kunci untuk mengurangi kemiskinan dan pertumbuhan ekonomi. Partisipasi angkatan kerja perempuan dan pendapatannya yang meningkat diasosiasikan dengan kemiskinan yang berkurang dan pertumbuhan yang lebih cepat. Sumber daya perempuan dapat diharapkan menjadi salah satu penggerak vital ekonomi melalui kemampuan mereka untuk menciptakan lapangan pekerjaan, meningkatkan kesejahteraan baik di tingkat keluarga, komunitas dan dalam International Management bahkan negara. Melalui partisipasi ekonomi perempuan ini diharapkan terwujud keadilan sosial ekonomi berperspektif gender di negara-negara Muslim.

\section{Penutup}

Islam telah memberikan landasan bagi pembangunan masyarakat yang berkeadilan termasuk dalam hal kesetaraan laki-laki dan perempuan. Namun penafsiran yang bias patriarki telah berkontribusi terhadap marjinalisasi perempuan, tidak terkecuali rendahnya partisipasi ekonomi perempuan di dunia Muslim. Menyikapi hal ini para ulama progresif berupaya melakukan penafsiran ulang terhadap teks-teks Alquran dan juga ketentuan-ketentuan syariat untuk menyuarakan Islam yang lebih berkeadilan. Dalam bidang ekonomi, penafsiran ulang ini juga 
diikuti dengan upaya peningkatan partisipasi ekonomi perempuan Muslimah dengan memberdayakan mereka untuk dapat mengakses hakhak ekonomi mereka seperti hak bekerja dan memperoleh pendapatan.

\section{Daftar Pustaka}

UU NO.7 Tahun 1984 Tentang Konvensi Mengenai Penghapusan Segala Bentuk Diskriminasi Terhadap Perempuan (CEDAW).

Garis-Garis Besar Haluan Negara Tahun 1999-2004 tentang Kedudukan dan Peranan Perempuan.

Ahmad Rifa'i. The Perfect Muslimah. Jakarta: PT. Elex Media Komputindo, 2012.

M. Dawan Rahardjo. Islam dan pembangunan ekonomi. Jakarta: Tazkia Institud, 2000.

M. Umer Chapra. Islam dan Pembangunan Ekonomi. Jakarta: Tazkia Institute, 2000.

Muhammad Husein. Islam Agama Ramah Perempuan. Yogyakarta: LkiS, 2004.

Nadia Abbot. Aishah: The Beloved of Muhammad. London: Saqi Books, 1985.

Peter R. Baehr. Hak-Hak Asasi Manusia dalam Politik Luar Negeri. Jakarta: Yayasan Obor Indonesia, 1998.

Quraish Shihab. Perempuan. Banten: Lentera Hati, 2015.

Revrisond Baswir, dkk. Pembangunan Tanpa Perasaan. Jakarta: ELSAM, 2003.

Sugiarti Handayani. Konsep dan Teknik Penelitian Gender. Malang: UMM Press, 2002.

Yeni Huriani, Encep Dulwahab, Nablurrahman Annibras. Strategi Penguatan Ekonomi Perempuan Berbasis Keluarga. 2021.

Bidang Pengarusutamaan Gender Bidang Ekonomi, Kebijakan dan Strategi Peningkatan Produktifitas Ekonomi Perempuan, Jakarta: Kementerian Pemberdayaan Perempuan \& Perlindungan Anak Republik Indonesia, 2012.

Suwarno Joyo Menggolo. Pemberdayaan Ekonomi Perempuan: Upaya Alternatif Membebaskan Perempuan dari Kesenjangan Ekonomi, https://www.infid.org/news/read/pemberdayaan-ekonomiperempuan-upaya-alternatif-membebaskan-perempuan-darikesenjangan-ekonomi. 2021. 